\title{
THE MIGRATION FLOW BETWEEN LITHUANIA AND SPAIN: A STUDY OF ECONOMIC FACTORS
}

\author{
Antonio MIHI-RAMÍREZ \\ University of Granada, Faculty of Economics and Management, \\ Campus Cartuja, 18071, Granada, Spain \\ E-mail: amihi@ugr.es \\ Dominik METELSKI \\ University of Granada, Faculty of Economics and Management, \\ Campus Cartuja, 18071, Granada, Spain \\ E-mail: dominik@trade2win.pl

\section{Aurimas RUDŽIONIS}

Kaunas University of Technology, Laisvès Av. 55, LT-44309 Kaunas, Lithuania E-mail: aurimas.rudzionis@ktu.lt

doi:10.13165/IE-13-7-4-02

\begin{abstract}
International migration has increased severely in the last decade in Europe, particularly between Lithuania and Spain. This research addressed trends of earnings and unemployment and their impact on both emigration and immigration in Spain and Lithuania, relying on the data coming from the period of 2000 till 2012. An empirical analysis of both countries using data from Eurostat and national statistics departments has shown evidence that emigration and immigration were continually growing, showing, however, different behavior in terms of imbalances on earnings and unemployment. Thus, in Spain, the main factor that affects emigration is unemployment, and earnings significantly affect immigration. In turn, the results for Lithuania have shown that the main factor that affects emigration is the level of earnings, and unemployment significantly affects immigration.
\end{abstract}

JEL classification: F, F22.

Keywords: economic migration, international migration, unemployment, earnings.

Reikšminiai žodžiai: ekonominè migracija, tarptautinė migracija, nedarbas, uždarbis.

\section{Introduction}

The European Union (EU) is characterized by rapid, paradoxical and complex changes, where globalization is an imperative and the economy has faced significant 
challenges over the last decade, in a period of economic stabilization followed by a financial downturn.

When looking, however, across different EU Member States, some important regional disparities can be spotted, with respect to economic factors, particularly in the case of earnings and unemployment rates (Stankevičienè, Gruodis, Lokutijevskij and Urbaite, 2012; Zimmermam, 1996) that could be pivotal in terms of economic incentives to emigrate.

Therefore, it is kind of a natural phenomenon to move to those places where a superior earnings and a higher probability of finding a job is expected (Cattaneo, 2008).

Immigration could be an opportunity, since it could have very positive effects for those people, who do not have enough economic opportunities in their home countries, in order to find a place in the labor market of the destination country and employment and better living conditions, and also for the host country, which could benefit from the immigrants flow if it is consistent with their socioeconomic and demographic characteristics.

Numerous research studies regarding international migration across Europe have been done. On the other hand, empirical studies reflecting impact of specific indicators on international migration have been rarely addressed in literature (Jenissen, 2003).

International migration between Spain and Lithuania has been growing steadily, especially ever since Lithuania joined the EU. This migration flow experienced important structural change due to imbalances in levels of earnings and unemployment pertinent for economies of both countries. It is worthwhile, however, to raise the point that addresses potential effects of earnings and unemployment on emigration and immigration. The aim of this research is to analyze the influence of earnings and unemployment as economic determinants on emigration and immigration in Spain and Lithuania in the last decade. The outline of this paper is as follows. It starts off by a theoretical background, where constructs and relations between certain variables are going to be defined, which have been reviewed from a theoretical perspective. Also, in the part below, the data and the methodology that the authors of this paper used is described. When it comes to the empirical study, the authors used correlation analysis and multiple regression analysis of earnings, unemployment, emigration, immigration for each country. Further, the results for each country are explained and discussed, including a comparison 'draw-up' between both countries. Finally, conclusions of this research study are set out.

\section{Theoretical framework}

Migration flow analysis usually entails an adjustment of inconsistencies in the collection of available data (De Beer et al., 2010). There are actually numerous definitions of analyzed constructs in terms of the comparison of international migration (Kupiszewska and Nowok, 2005). Therefore, in this research definitions of immigration and emigration provided by the Official Journal of the European Union are used (Official Journal of the European Union, 2007: 24). Immigration is defined there as "the action by which a person establishes his or her usual residence in the territory of a Member State for a period that is, or is expected to be, of at least 12 months, having previously been usually resident in another Member State or a third country". Emigration can be defined also as 
"the action by which a person, having previously been usually resident in the territory of a Member State, ceases to have his or her usual residence in that Member State country for a period that is, or is expected to be, of at least 12 months".

Regarding the earnings, the authors studied average net annual earnings of employees of all companies, in which they had been employed for a full year. Gross earnings correspond to remunerations before any tax deductions and social security contributions payable by wage earners and retained by the employer. Net earnings are "calculated from gross earnings by deducting the employee's social security contributions and income taxes, and adding family allowances in the case of households with children" (Eurostat, 2013). Therefore, net earnings represent actual income and it helps to get a better picture of emigrants and immigrants.

The definition of unemployment is raised by the Commission Regulation (EC) No. 1897/2000. Unemployed persons are all persons between 15 and 74 years of age, who were not employed during the reference week, had actively sought for work during the past four weeks and were ready to begin working immediately or within two weeks (Eurostat, 2013).

When it comes to migration, it is confirmed that Spain has always played a role of a host country for immigrants from South America, although during last couple of years emigration has developed again due to the economic crisis (Mihi-Ramírez, 2013; MihiRamírez and Kumpikaitè, 2013). Lithuania has always been a sending country in terms of migration flow, with people migrating mostly to North Europe, England and the United States. On the other hand, Lithuania has received immigrants mainly from neighboring countries, such as the Republic of Belarus, Latvia and Estonia (Kovalenko et al., 2010). Nevertheless, migration flow between both countries has been continually growing in the last decade and it showed evidence of certain discrepancies between its economic stabilization phase and its crisis phase.

From the perspective of neo-classical economic theory, migration flow happens because of important regional differences on the level of earnings and unemployment (Jennissen, 2003; Zimmermam, 1996).

According to Keynesian economic theory, money is not only a mean of exchange, but also a mean of saving (Jennissen, 2003). Hence, high nominal earnings determine international migration, what further leads to an adjustment of unemployment levels.

This study purports evidence of a relation between host country higher earnings and a higher number of immigrants. That being the case, a reduction of imbalances with respect to levels of earnings or unemployment could encourage returns of emigrants (Boman, 2011).

Likewise, in periods of relative economic prosperity in sending countries, a rising level of earnings and unemployment positively affects international migration.

Further, low earnings do not stimulate employment since unemployed people can get social assistance, work in the grey market or emigrate (Kovalenko et al., 2010).

Kovalenko et al. (2010) purported that more unbalanced earnings distribution in a host country compared with a home country leads to a higher emigration in a short-term.

Analysis presented by Gaag and Wissen (2008) showed that unemployment is the most important economic indicator affecting international migration in Germany, the Netherlands and England. 
According to Stankevičienè et al. (2012), unemployment is one of the most observable indicators of economic activity and it is highly related to the unemployment. These authors addressed that there is an inverse relationship, so when one indicator is falling, the other follows with the increase.

Leslie et al. (1998), in turn, found that in the United Kingdom unemployment's imbalance is more of a problem when compared with earnings imbalance.

Also, what plays a pivotal role in migration decisions making is expected earnings and employment prospects (Sjaastad, 1962). When earning conditions remain balanced both in sending and host countries, therefore, a strong positive correlation exists between immigrants expected earnings in home and host countries (Borjas, 1987).

In addition, Boman (2011) purported that immigrants decide to stay in new locations when their earnings increase.

Pekkala and Tervo (2002) analyzed the case of Norway and Sweden and their research showed evidence that in a long run a higher unemployment much rather encouraged Norwegians to migrate to Sweden, where they expected to succeed in finding new jobs, whilst people, who decided to stay in their native countries, proved to be less successful.

\section{Methodology}

The main objective of this study is to analyze the influence of earnings and unemployment on economic migration flow. The analysis addresses two countries, namely Lithuania and Spain, in the period of 2000 to 2012.

The authors used annual data (13 observations corresponding to years 2000-2012) that were obtained from the Statistical Office of the European Communities (Eurostat, 2013), the Lithuanian Department of Statistics (Statistics Lithuania, 2013) and the National Statistics Institute of Spain (INE, 2013). Further, several statistical problems are addressed with respect to migration data (Kupiszewska and Nowok, 2005; Moody and Puffer, 1969). Consequently, to facilitate comparison of migration data taken from Eurostat, the authors used a correction factor so that it would enhance and harmonize emigration and immigration data (De Beer et al., 2010).

The approach is focused on the analysis of earnings and unemployment. The authors relied on certain variables that affect emigration and immigration in Spain and Lithuania, with the purpose of comparing the results between both countries. Regarding net earnings, the data refer to the most typical case in emigration and immigration (Arah et al., 2008), it is a married couple with two children who both earn $100 \%$ of average earnings of an average worker in industry and services at national level (Eurostat, 2013).

Other studies addressed a much rather multiple linear regression for the purposes of analyzing the migration flow, e.g., a study conducted by Zimmermam (1996), where correlations and regressions were employed to analyze migration flow in Europe. Zimmerman relied mostly on the case of Germany when providing evidence. Leslie et al. (1998) investigated earnings and unemployment in the United Kingdom. Zhan (2003) analyzed rural and urban migration in China. Dreher and Poutvaara (2006) studied mi- 
gration of students in the United States. Arah et al. (2008) studied relations of migration in developing source countries and in more developed host countries. Vojtovich (2013) examined GDP, unemployment and migration in Slovakia. Following his approach, correlation analysis was used to test relations between explanatory variables, such as earnings and unemployment, and endogenous variables - immigration and emigration. These relations were contrasted using multiple linear regression analysis. Table 1 summarizes results for Spain and Lithuania.

\subsection{Results}

First, correlation coefficients were calculated to examine to what extent associated were the predictors (Arah et al., 2008), i.e., earnings and unemployment with endogenous variables: emigration and immigration.

Further, the authors used multiple linear regressions to examine relationships among correlated variables (Arah et al., 2008) (see Table 1):

- how earnings and unemployment affect emigration in Spain;

- how earnings and unemployment affect immigration in Spain;

- how earnings and unemployment affect emigration in Lithuania;

- how earnings and unemployment affect immigration in Lithuania.

Table 1. Standardized parameter estimates of the determinants of emigration and immigration: Spain 2000-2012

\begin{tabular}{|c|c|c|c|c|c|}
\hline & \multicolumn{2}{|c|}{ Emigration } & \multicolumn{2}{|c|}{ Immigration } \\
\hline & & Spain & Lithuania & Spain & Lithuania \\
\hline \multicolumn{2}{|l|}{ Constant } & $\begin{array}{c}-876065,07 \\
(-7,21)\end{array}$ & $\begin{array}{c}-64581,88 \\
(-2,91)\end{array}$ & $\begin{array}{c}-727566,8 \\
(-3,43)\end{array}$ & $\begin{array}{c}2886,69 \\
(0,489)\end{array}$ \\
\hline \multicolumn{2}{|l|}{ Earning } & $-188,78(6,27)$ & $-22,11(3,76)$ & $187,04(7,4)$ & $22,16(2,85)$ \\
\hline \multicolumn{2}{|c|}{ Unemployment } & $240,53(2,81)$ & $162,99(2,64)$ & $-240,32(9,42)$ & $-10,17(2,97)$ \\
\hline \multicolumn{2}{|c|}{$\begin{array}{l}\text { Person's correlation coefficient } \\
\mathrm{R}(\mathrm{X}, \mathrm{Y})\end{array}$} & 0,98 & 0,80 & 0,95 & 0,79 \\
\hline \multicolumn{2}{|c|}{ Coefficient of deermination R2 } & 0,96 & 0,64 & 0,90 & 0,57 \\
\hline \multicolumn{2}{|c|}{ Durbin-Wats on } & 1,69 & 1,79 & 1,63 & 1,69 \\
\hline \multicolumn{2}{|c|}{ F-Snedecor } & 0,60 & 0,10 & 0,70 & 0,60 \\
\hline \multirow[t]{2}{*}{ Average } & Earning & 10770,21 & 2541,83 & & \\
\hline & Unemployment & 2948,85 & 184,25 & & \\
\hline \multirow{2}{*}{$\begin{array}{l}\text { Standard } \\
\text { Deviation }\end{array}$} & Earning & 1426,67 & 840,57 & & \\
\hline & Unemployment & 1402,46 & 80,32 & & \\
\hline \multirow{2}{*}{$\begin{array}{l}\text { Kolmogorov- } \\
\text { Smirnov }\end{array}$} & Earning & 0,66 & 0,64 & & \\
\hline & Unemployment & 1,11 & 0,5 & & \\
\hline
\end{tabular}

dependent variables: emigration, immigration explanatory variables: unemployment, earnings Numbers in parentheses are $t$-statistics 
Pertinent variables subject of this study followed a normal distribution (K-S test) and the models met assumptions with respect to linearity $(\mathrm{R}(\mathrm{X}, \mathrm{Y}))$, independence (Durbin-Watson) and homoscedasticity (p. F-Snedecor) (Arah et al., 2008).

In Spain, correlation coefficients showed that emigration is strongly associated with unemployment $(\mathrm{r}=0.883, \mathrm{P}<.001)$ and earnings $(\mathrm{r}=-0.780, \mathrm{P}<.001)$ and, taking into account the results of multiple linear regressions in Table 1, it was observed that higher unemployment or lower earnings cause higher emigration, especially in the case of higher unemployment. Immigration is also associated with unemployment $(\mathrm{r}=-0.854$, $\mathrm{P}<.005)$ and earnings $(\mathrm{r}=0.877, \mathrm{P}<.005)$, so that lower unemployment or higher earnings cause higher immigration, especially in the case of lower earnings.

Similarly, earnings are associated with unemployment $(\mathrm{r}=-0.707, \mathrm{P}<.001)$ and emigration is associated positively with immigration $(\mathrm{r}=0.982, \mathrm{P}<.005)$.

What regards Lithuania, emigration showed evidence of significant correlation with immigration $(\mathrm{r}=0.986, \mathrm{P}<.001)$, unemployment $(\mathrm{r}=0.786, \mathrm{P}<.001)$ and earnings $(\mathrm{r}=-0.817, \mathrm{P}<.001)$, so it was observed that higher unemployment or lower earnings cause higher emigration, especially when earnings are lower. In turn, immigration is strongly associated with unemployment $(r=-0.912, \mathrm{P}<.005)$ and earnings $(\mathrm{r}=0.724$, $\mathrm{P}<.001$ ), so that lower unemployment or higher earnings cause higher immigration, especially in the case of higher unemployment. Similarly, earnings are associated with unemployment $(\mathrm{r}=-0.912, \mathrm{P}<.001)$.

\subsection{Discussion}

In both countries, the authors of this study found evidence of all analyzed variables being associated with each other and the evidence proved to be statistically significant (Table 1).

In Spain, variability of earnings and unemployment explains $96 \%$ of the variability of emigration (see Table 1). The results showed that the level of unemployment is a positive determinant of emigration.

Additionally, graphical analysis was also used based on official statistics data showing the results in a more intuitive way. Thus, Figure 1 shows emigration, immigration and unemployment (per 1000 habitants) in the period of 2000-2012, where left scale represents unemployment and right scale includes emigration and immigration data. It is annual data collected from Eurostat and Spanish Statistics Office (INE).

Figure 1 portrays an economic stabilization period that sustained till 2007 with a relatively stable level of unemployment. There is an increasing number of immigrants and a low number of emigrants, but from 2007 onwards unemployment began to raise continuously, so the number of immigrants started to reduce significantly and the number of emigrants increased. What is more to the point, emigration exceeded immigration in 2011 already. 
Figure 1. Emigration, immigration and unemployment (per 1000 hab.). Spain 2000-2012.

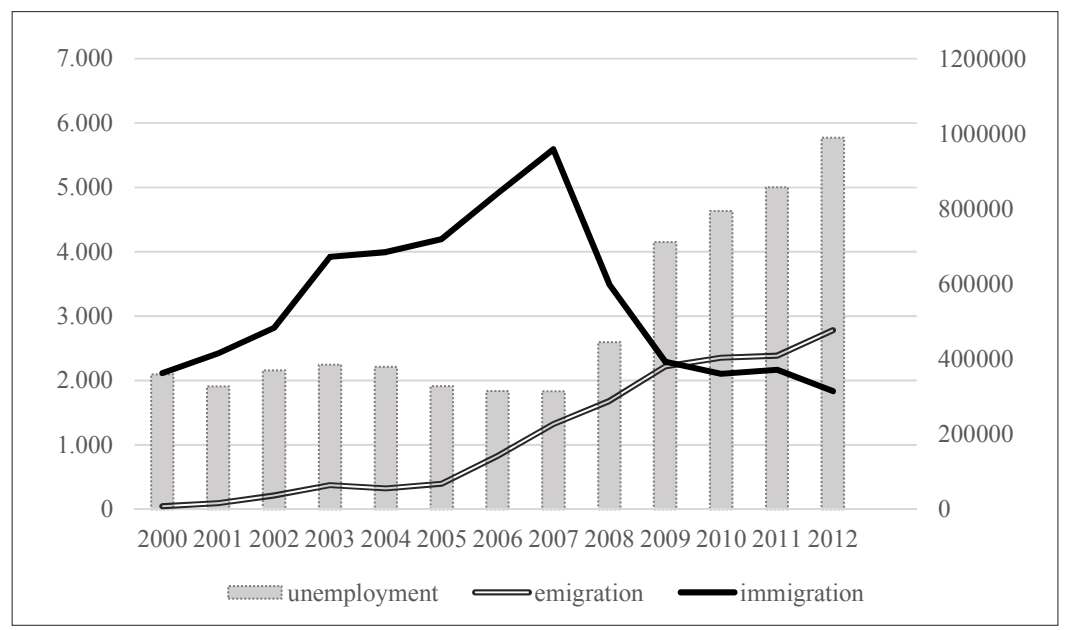

Source: Eurostat, INE Spain

Figure 2 shows emigration, immigration and net annual earnings during the period of 2000-2012, where left scale represents earnings in euros and right scale includes emigration and immigration data, which is annual data collected from Eurostat and Spanish Statistical Office (INE).

Figure 2. Emigration, immigration and net annual earnings (€). Spain 2000-2012.

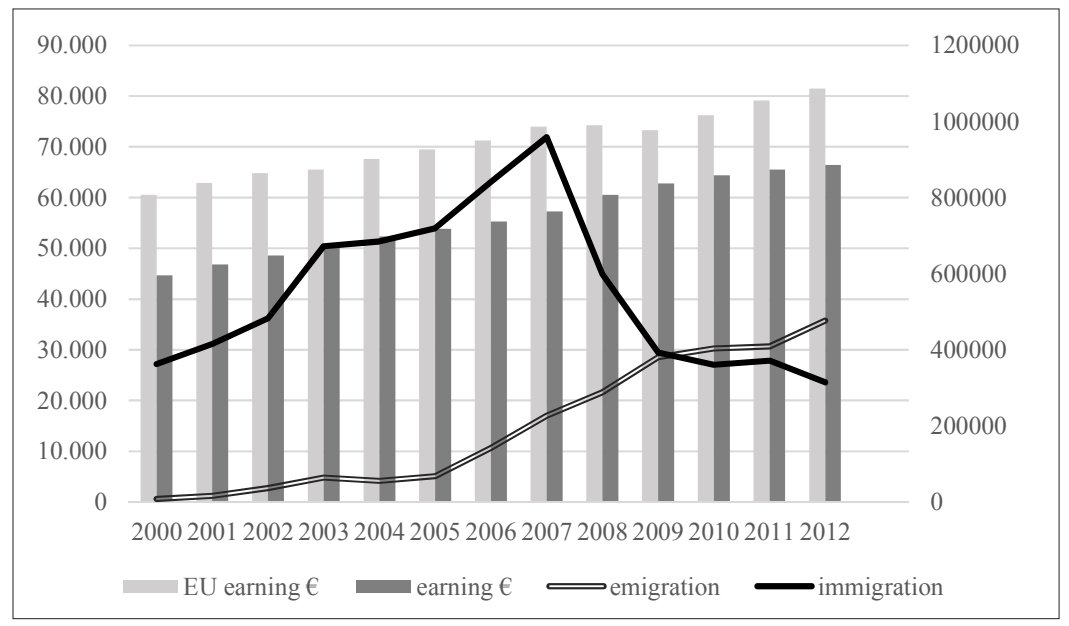

Source: Eurostat 
Although unemployment is the most determining variable of emigration, the results showed that earnings significantly affected immigration.

Moreover, according to Eurostat, data earnings in Spain were lower than the European Union average and barely increased until 2007, and after that year, its growth was even lower. Therefore, the highest increase of unemployment in Europe after 2007 that Spain experienced caused higher emigration and a severe reduction of immigration.

In Lithuania, variability of earnings and unemployment explains $64 \%$ of the variability of emigration (see Table 1). The results that were obtained showed earnings being the pivotal determinant of emigration, and unemployment determinates immigration.

Figure 3 shows emigration, immigration and unemployment (per 1000 habitants) in the period of 2000-2012, where left scale represents unemployment and right scale includes emigration and immigration data, which is annual data collected from Eurostat and Lithuanian Department of Statistics (Statistics Lithuania). In addition, Figure 4 shows emigration, immigration and net annual earnings during the period of 2000-2012, where left scale represents earnings in euros and right scale includes emigration and immigration data. It is annual data collected from Eurostat and Statistics Lithuania.

Figure 3. Emigration, immigration and unemployment (per 1000 hab.). Lithuania 2000-2012.

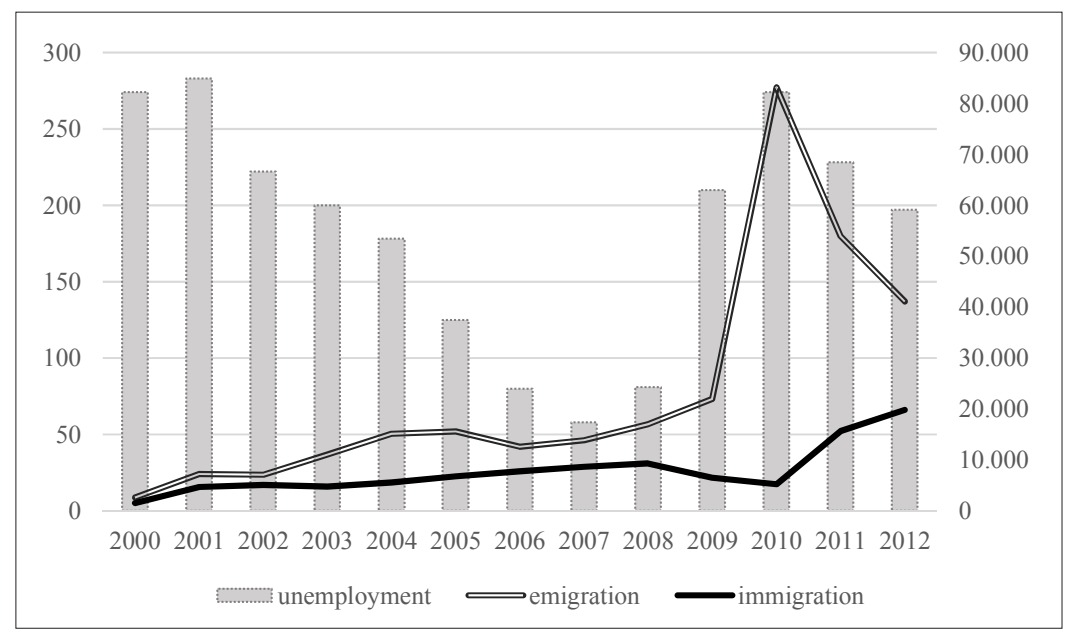

Source: Eurostat and Statistics Lithuania 
Figure 4. Emigration, immigration and gross annual earnings (€). Lithuania 2000-2012.

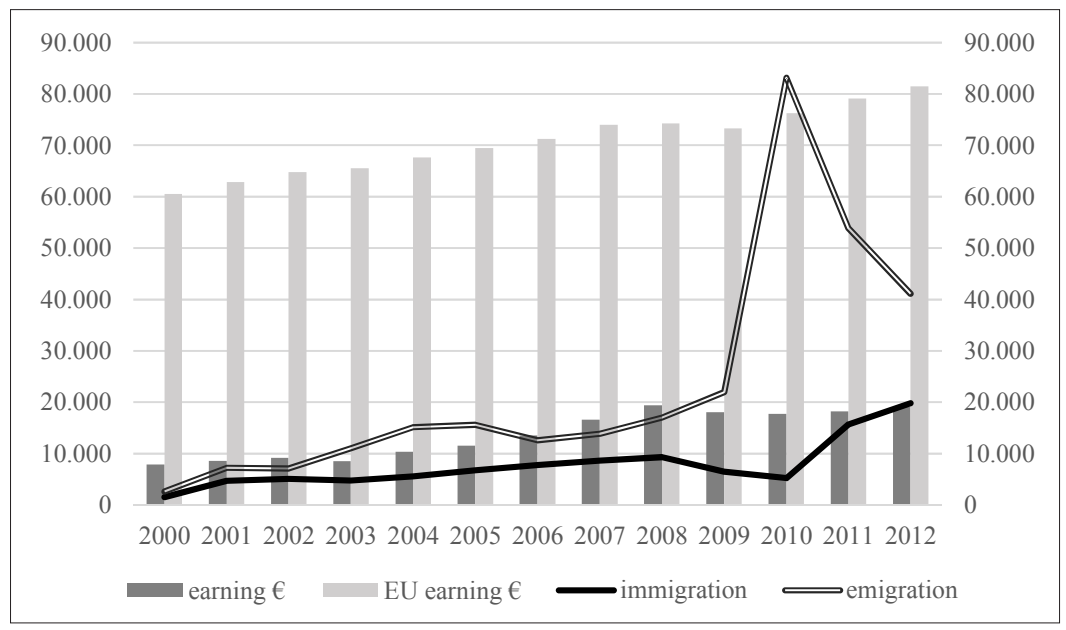

Source: Eurostat and Statistics Lithuania

Thus, it can be observed from Figures 3 and 4 that until 2007 earnings level was very low in comparison with the EU average and it barely increased in the course of time, so emigration was superior than immigration, especially ever since Lithuania joined the European Union in 2004 (Kovalenko et al., 2010). From 2007 onwards, earnings were still raising, though with lower pace. In turn, earnings deterioration together with higher unemployment reduced the likelihood of re-employment (Boman, 2011). Therefore, the number of emigrants increased dramatically, but the economic crisis pertinent to host countries, such as Spain, where earnings and unemployment worsened severely, recently has caused a reduction of the number of emigrants and, for the first time in the analyzed period, also a slight increase of immigrants.

This situation is explained in Figure 5. The number of Lithuanians in Spain increased massively from 2004 onwards and it stabilized starting from 2007 already. In the same time, Lithuanians, who lived in Spain, returned to Lithuania, what took place particularly from 2008 onwards, when earnings and unemployment deteriorated in Spain. In turn, emigration of Spaniards to Lithuania remained low but was gradually increasing from 2008 onwards.

Taking into consideration these results, it could be said that earnings and unemployment act as migration pull and push factors in both countries. Disparities in levels of earnings and unemployment affect migration flow (Cattaneo, 2008; Lee, 1966; Zimmermam, 1996).-Consequently, the authors of this study point to those regions with higher level of earnings as the ones that would attract more Lithuanians to Spain. In turn, regions with a lower unemployment level are the ones that would attract Spaniards to Lithuania (see Figure 6). 
Figure 5. Emigration and immigration between Spain and Lithuania during the period of 2000-2012.

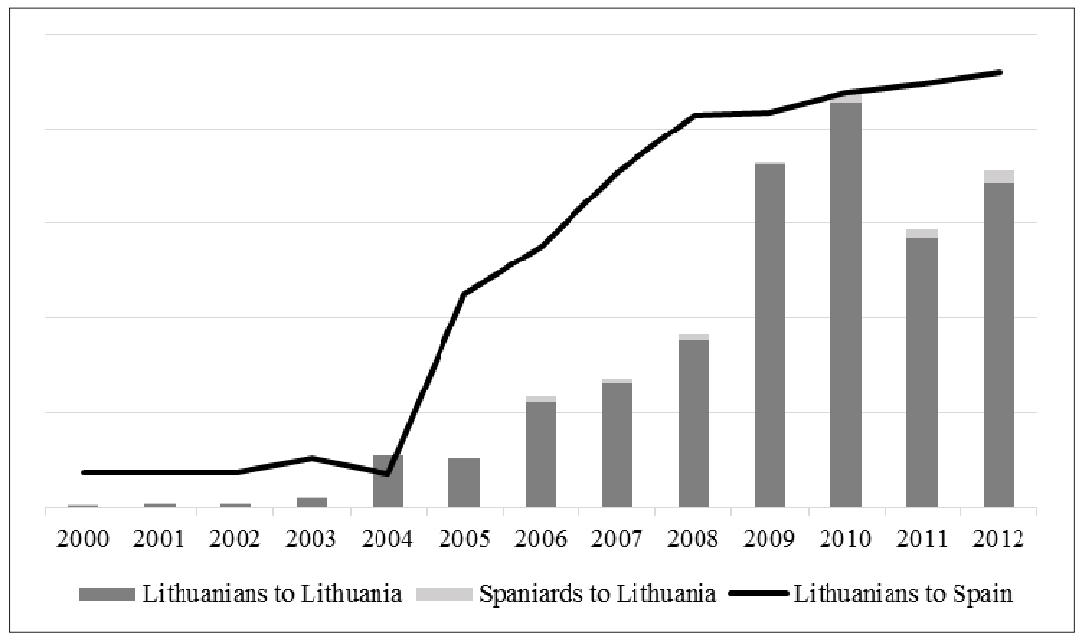

Source: INE, Statistical Lithuania

Figure 6. Immigrants from Spain and Lithuania by regions in 2012.

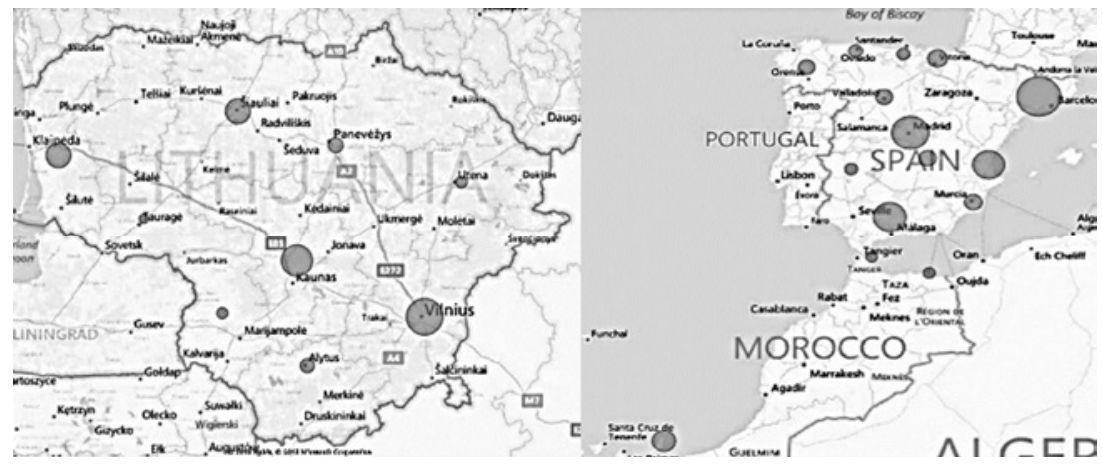

Source: INE, Statistical Lithuania

\section{Conclusions}

Migration flow between Spain and Lithuania has increased severely in the last decade, especially since Lithuania joined the EU.

The study focuses on earnings and unemployment and their impact on economic migration between both countries in the last decade. 
In the analysis of both countries, evidence that earnings, unemployment, emigration and immigration are highly associated with each other was found.

Emigration and immigration were continually growing, showing, however, different behavior in terms of imbalances on earnings and unemployment. These variables acted as economic pull and push factors over time.

In Spain, increasing unemployment and earnings that almost stayed at a flat level caused higher emigration and reduced immigration. During the last economic stabilization period in Europe, relatively low unemployment and higher earnings attracted numerous immigrants and Spain became one of the most important international destinations for immigrants. In the same period, emigration remained on a quite low level in Spain. However, since 2007, international economic situation started to worsen, unemployment became continuously raising and an unchanged level of earnings caused a strong reduction of immigration and increased emigration.

In Lithuania, lower levels of earnings and unemployment maintained higher emigration, whilst in the same time, immigration was raised only slightly. Thus, Lithuania was a sending emigrant's country for the most part but starting from 2007 onwards low earnings and the decline of unemployment caused a massive emigration. Due to the international economic crisis in traditional host countries, such as Spain, the situation worsened enough so that a small increase of emigrants, including Lithuanians who returned back home, could be observed.

Unemployment and earnings are the main factors that delineate emigration and immigration and constitute important economic determining factors of international migration in Spain and Lithuania.

Differences in levels of earnings and unemployment between both countries affect the flow of migration between them. For a sending country, lower imbalances encourage emigrants return and immigration, whilst in a host country, higher imbalances attract immigrants and add to emigration.

\section{References}

1. Arah, O.A.; Ogbu, U.C.; Okeke, C.E. MD Too Poor to Leave, Too Rich to Stay: Developmental and Global Health Correlates of Physician Migration to the United States, Canada, Australia, and the United Kingdom. American Journal of Public Health. 2008, 98(1): 148-154.

2. Boman, A. Does Migration Pay? Earnings Effects of Geographic Mobility Following Job Displacement. Journal Population Economics. 2011, 24: 1369-1384.

3. Borjas, G. Self-selection and the Earnings of Immigrants. American Economic Review. 1987, 77(4): 531-553.

4. Cattaneo, C. The Determinants of Actual Migration and the Role of Wages and Unemployment in Albania: An Empirical Analysis. The European Journal of Comparative Economics. 2008, 5(1): 3-32

5. De Beer, J.; Raymer, J.; Van der Erf, R.; Van Wissen, L. Overcoming the Problems of Inconsistent International Migration Data: A New Method Applied to Flows in Europe. European Journal of Population. 2010, 26: 459-481. 
6. Dreher, A.; Poutvaara, P. Student Flows and Migration: An Empirical Analysis. Helsinki Center of Economic Research, Discussion Paper. 2006, 100: 1-27.

8. Jennissen, R. Economic Determinants of Net International Migration in Western Europe. European Journal of Population. 2003, 19(2): 171-198.

9. Kovalenko, J.; Mensah, P.; Leončikas, T.; Žibas, K. New Immigrants in Estonia, Latvia and Lithuania. Legal Information Centre for Human Rights. Network of European Foundations for Innovative Cooperation within the European Programme for Integration and Migration, 2010.

10. Kupiszewska, D.; Nowok, B. Comparability of Statistics on International Migration Flows in the European Union. Central European Forum for Migration and Population Research, Working Paper. 2005, 7: 1-40.

11. Lee, E. A Theory of Migration. Demography. 1966, 3(1): 47-57.

12. Leslie, D.; Drinkwater, S.; O'Leary, N. Unemployment and Earnings among Britain's Ethnic Minorities: Some Signs for Optimism. Journal of Ethnic and Migration Studies. 1998, 24(3): 489-506.

13. Lithuanian Department of Statistics, Statistics Lithuania [interactive]. [accessed on 15-03-2013]. <http://osp.stat.gov.lt/en/statistiniu-rodikliu-analize1>.

14. Moody, H.T.; Puffer, F.W. Some Statistical Problems in Migration Analysis. The Annals of Regional Science. 1969, 3(2): 192-201.

15. Mihi-Ramírez, A. The 180 Degree Turn about Economic Migrants Flow. An Analysis of the Case of Spain and Latin America. Public Policy and Administration. 2013, 12(1): 9-21.

16. Mihi-Ramírez, A.; Kumpikaite, V. The European Migration Flow in a Context of Deterioration of Economic Factors. The Case of Spain. Economics and management. 2013, 18(3): 1-9.

17. National Statistics Institute of Spain, INE [interactive]. [accessed on 15-03-2013]. $<$ http://www.ine.es/en/welcome.shtml .

18. Official Journal of the European Union. Regulation (EC) No. 862/2007 of the European Parliament and of the Council of 11 July 2007 on Community statistics on migration and international protection and repealing Council Regulation (EEC) No. 311/76 on the compilation of statistics on foreign workers. 2007 [interactive]. [accessed on 15-03-2013]. <http://eur-lex.europa.eu/LexUriServ/LexUriServ.do?ur $\mathrm{i}=\mathrm{OJ}: \mathrm{L}: 2007: 199: 0023: 0029: \mathrm{EN}: \mathrm{PDF}>$.

19. Pekkala, S.; Tervo H. Unemployment and Migration: Does Moving Help? Scandinavian Journal of Economics. 2002, 104(4): 621-639.

20. Sjaastad, L. The Costs and Returns of Human Migration. Journal of Political Economy. 1962, 5(70): 80-93.

21. Stankevičienè, J.; Gruodis, A.; Lokutijevskij, A.; Urbaite, U. Building Lithuanian Macro-econometric Model: Forecast of Average Wages and Unemployment Rate. Intelektine Ekonomika [Intellectual Economics]. 2012, 6(1), 13: 754-775.

22. Van der Gaag, N.L.; Van Wissen, L.J.G. Economic Determinants of Internal Migration Rates: A Comparison Across Five European Countries. Tijdschrift voor Economische en Sociale Geografie. 2008, 99(2): 209-222.

23. Statistical Office of the European Communities, Eurostat [interactive]. [accessed on 15-03-2013]. <http://epp.eurostat.ec.europa.eu/portal/page/portal/eurostat/home/>. 
24. Vojtovich, S. The Impact of Emigration on Unemployment in Slovakia. Inzinerine Ekonomika-Engineering Economics. 2013, 24(3): 207-216.

25. Zhan, K.H. Rural-urban Migration and Urbanization in China: Evidence from Timeseries and Cross-section Analyses. China Economic Review. 2003, 14: 386- 400.

26. Zimmermam, K. F. European Migration: Push and Pull. International Regional Science Review. 1996, 19(1 \& 2): 95-128.

\section{MIGRACIJOS SRAUTAI TARP LIETUVOS IR ISPANIJOS: EKONOMINIŲ VEIKSNIŲ ANALIZE்}

Santrauka. Per pastarajj dešimtmetị Europoje labai išaugo tarptautinè migracija, ypatingai tarp Lietuvos ir Ispanijos valstybių. Autoriai analizuoja darbo užmokesčio bei nedarbo veiksnių įtaką emigracijai bei imigracijai Ispanijoje ir Lietuvoje remiantis 2000-2012 metų statistikos duomenimis. Empirinè abiejų šalių analizè, naudojantis Eurostato ir nacionalinių statistikos departamentų duomenimis, parodè akivaizdų nuolatinị emigracijos bei imigracijos augimą, tačiau abiejų šalių gyventojų elgesys buvo skirtingas kalbant apie disbalansą tarp darbo užmokesčio bei nedarbo. Taigi, pagrindinis veiksnys, skatinantis emigraciją Ispanijoje, yra nedarbas, tuo tarpu imigracijai ženkliai įtakos turi darbo užmokestis šioje šalyje. Tyrimo rezultatai parodè, kad pagrindinis veiksnys Lietuvoje, turintis ịtakos emigracijai, yra darbo užmokesčio lygis, o imigraciją skatina nedarbo lygis.

Antonio MIHI-RAMíREZ, Granada University, Faculty of Economics and Management, Department of International and Spanish Economics, PhD. Research interests: economics and international migration.

Antonio MIHI-RAMÍREZ - Granados universiteto Ekonomikos ir vadybos fakulteto Tarptautinès ir Ispanijos ekonomikos katedros profesorius, socialinių (ekonomikos ir vadybos) mokslų daktaras. Mokslinių interesų sritys: ekonomika ir tarptautinė migracija.

Dominik METELSKI, Granada University, Faculty of Economics and Management, PhD (Economics) student. Research interests: economics and international migration.

Dominik METELSKI - Granados universiteto Ekonomikos ir vadybos fakulteto socialinių (ekonomikos) mokslų doktorantas. Mokslinių interesų sritys: ekonomika ir tarptautiné migracija.

Aurimas RUDŽIONIS, Kaunas University of Technology (Lithuania), Faculty of Economics and Management, MSc in Business. Research interests: economics and international migration.

Aurimas RUDŽIONIS - Kauno technologijos universiteto Ekonomikos ir vadybos fakulteto magistras. Mokslinių interesų sritys: ekonomika ir tarptautinė migracija. 